\title{
PENGARUH TASK COMMITMENT DAN LOCUS OF CONTROL TERHADAP PRESTASI BELAJAR MATEMATIKA
}

\author{
Juminah \\ SMK Tarbiyatul Islam Kawunganten, \\ Jln. Kawunganten Lor, Kawunganten, Cilacap, Jawa Tengah. \\ e-mail: juminah_zumm@yahoo.co.id
}

\begin{abstract}
Abstrak: Pengaruh Task Commitment dan Locus of Control terhadap Prestasi Belajar Matematika. Manfaat dari penelitian ini adalah untuk menganalisis pengaruh task commitment dan locus of control terhadap prestasi belajar matematika. Metode yang digunakan dalam penelitian ini adalah metode survai dengan analisis korelasional. Instrumen yang digunakan dalam bentuk angket sebanyak 30 soal pernyataan dan sudah divalidasi secara empirik. Hasil penelitian dilakukan analisis ANAVA dua arah dan mendapatkan hasil sebagai berikut: Hipotesis pertama terdapat pengaruh interaksi antara task commitment dan locus of control terhadap prestasi belajar matematika. Hipotesis kedua terdapat pengaruh yang signifikan task commitment tinggi dan task commitment rendah terhadap prestasi belajar matematika. Hipotesis ketiga terdapat pengaruh yang signifikan antara locus of control internal dan locus of control eksternal terhadap prestasi belajar matematika. Hipotesis keempat, sebagai berikut: (a) Menunjukkan adanya pengaruh task commitment tinggi dan task commitment rendah pada locus of control internal; (b) Menunjukkan adanya pengaruh task commitment tinggi dan task commitment rendah pada locus of control eksternal; (c) Menunjukkan adanya pengaruh locus of control internal dan locus of control eksternal pada task commitment tinggi; (d) Menunjukkan adanya pengaruh locus of control internal dan locus of control eksternal pada task commitment rendah. Secara keseluruhan peneliti menyimpulkan bahwa terdapat pengaruh baik secara bersama-sama maupun secara terpisah antara task commitment dan locus of control terhadap prestasi belajar matematika.
\end{abstract}

\section{Kata Kunci: Task Commitment, Locus of Control, Prestasi Belajar Matematika.}

\begin{abstract}
The impacts of task commitment and locus of control on mathematical learning achievement. The benefits of the research is to analyze the impacts of task commitment and locus of control on mathematical learning achievement. The method used in this research is survey method with corrasional analysis. The instrument used is 30 questionnaire and have been empirically validated. The research used two way Anova analysis and the result show that. First hypothesis, there are interaction impacts of task commitment and locus of control on mathematical learning achievement. Second hypothesis, there are significant impacts of high task commitment and low task commitment on mathematical learning achievement. Third hypothesis, there are significant impacts of internal locus of control and exsternal locus of control on mathematical learning achievement. Fourth hypothesis show that, a) there are impacts of high task commitment and low task commitment on internal locus of control, b) there are impacts of high task commitment and low task commitment on exsternal locus of control, c) there are significant impacts of internal locus of control and exsternal locus of control on high task commitment, d) there are significant impacts of internal locus of control and exsternal locus of control on low task commitment. So, the writer concluded that there are impacts of both all together and separately between task commitment and locus of control on mathematical learning achievement.
\end{abstract}

Keywords: Task Commitment, Locus of Control, Mathematical Learning Achievement. 


\section{PENDAHULUAN}

Pendidikan merupakan salah satu hal yang penting dalam kehidupan berbangsa dan bernegara. Kontribusi pendidikan bagi negara sangat besar dalam meningkatkan kualitas sumber daya manusia di masa mendatang. Sumber daya manusia yang berkualitas dan mampu bersaing adalah salah satu faktor penentu dalam peningkatan segala aspek kehidupan berbangsa dan bernegara. Melihat begitu pentingnya pendidikan, menjadikan pendidikan sebagai hal yang wajib dilaksanakan secara berkesinambungan guna menjawab tantangan dan perubahan zaman. Berpijak dari kebutuhan di masa mendatang, maka diperlukan perhatian yang khusus dalam penyelenggaraan pendidikan yang berkualitas.

Menyelenggarakan menciptakan pendidikan berkualitas yaitu pendidikan dengan sumber daya manusia berkualitas, yang tidak hanya mengandalkan pemerintah saja, melainkan dibutuhkan dukungan dari berbagai pihak. Dalam hal ini adalah peserta didik dan guru sebagai subjek pendidikan dan masyarakat sebagai faktor pendukung terbesar. Akan tetapi masih ditemukan masing-masing faktor tidak berjalan sebagaimana semestinya. Sekolah sebagai tempat terlaksana proses belajar mengajar merupakan tempat peserta didik menghabiskan sebagian besar waktu mereka. Peserta didik sebagai subjek pendidikan merupakan individu yang kompleks. Dikatakan kompleks karena setiap individu tidaklah sama, setiap individu mempunyai sifat, watak, perilaku maupun karakter berbeda-beda.

Proses pengembangan peserta didik terdapat banyak hal yang dapat mempengaruhi maupun dapat merubah karakter setiap individu. Bukan hanya proses perkembangan seorang individu mudah terpengaruh oleh hal-hal dari luar tetapi juga dalam proses belajar. Beberapa kendala lain yang cukup besar pengaruhnya, secara khusus di kalangan pelajar antar lain masih rendanya disiplin, kurangnya minat baca, serta kurang tingginya minat belajar. Kendala-kendala inilah yang menjadi batu sandungan bagi para penduduk muda usia yang kelak akan mencerminkan jati diri suatu bangsa. Beberapa guru dan ahli psikologi telah mencoba mengidentifikasi masalahmasalah yang terjadi di dalam kelas, salah satunya adalah komitmen terhadap tugas yang rendah, inisiatif dan keterlibatan belajar yang rendah, motivasi berprestasi yang kurang, yang dapat dinyatakan dalam kurangnya keterlibatan berpartisipasi dalam pekerjaan-pekerjaan di dalam kelas (Djiwandono, 2002: 321).

Proses belajar merupakan proses yang paling penting dalam pembelajaran yang bertujuan menghasilkan perubahan dalam pengetahuan, pemahaman, penerapan, analisis, sintesis, dan evaluasi. Karena kondusif atau tidaknya proses belajar menjadi penentu prestasi belajar yang didapatkan. Dalam proses ini seseorang memerlukan kedisiplinan, percaya diri, minat, bakat, kreativitas, efikasi diri, kendali diri (locus of control) dan faktor-faktor lain yang mendukung proses belajar. Melalui hasil belajar diketahui apakah proses belajar telah berjalan secara efektif atau belum. Untuk itu, guru memberikan tugas tes tertulis yang dikerjakan di kelas dan di rumah. Dengan demikian, dapat diketahui seberapa besar pengalaman belajar yang dipahami peserta didik.

Kesulitan yang dialami peserta didik biasanya pada mata pelajaran Matematika, Fisika, Kimia maupun Biologi. Matematika dianggap sebagian peserta didik sukar dan biasanya belajar matematika memerlukan kosentrasi 
tinggi. Saat ini masih banyak peserta didik yang mengalami kesulitan belajar matematika. Mereka menganggap matematika sebagai suatu mata pelajaran yang membosankan, menakutkan, menjadi beban bagi peserta didik karena bersifat abstrak, penuh dengan angka dan rumus. Selain itu, masih adanya sistem belajar yang menyamakan kemampuan peserta didik, kurangnya motivasi dari guru, sikap guru di dalam kelas, dan metode pengajaran yang tidak tepat.

Pada saat peserta didik belum menguasai materi dasar, sudah ditambah lagi dengan materi lainnya. Para peserta didik pun cenderung tidak menyukai matematika, karena dianggap sulit terutama dalam menyelesaikan soal-soal yang diberikan oleh guru matematika. Dari berbagai kesulitan tersebut telah banyak yang dilakukan oleh pemerintah, mulai dari kurikulum 2013 yang baru dilaksanakan walaupun di beberapa sekolah diganti lagi dengan kembali menerapkan KTSP, uji kompetensi guru dan peningkatan kesejahteraan guru untuk memberikan semangat pada guru-guru agar lebih meningkatkan kinerjanya.

Adanya krisis komitmen terhadap tugas (task commitment) yang terjadi di sebagian peserta didik menengah dapat mempengaruhi perkembangan sistem pendidikan di Indonesia yang menjadi sarana meningkatkan kualitas sumber daya manusia Indonesia. Seperti yang dikemukaan Renzulli (Dyah, 2009: 5) suatu masalah memerlukan komitmen internal individu dan kelompok pelakunya. Sama dengan sistem pendidikan yang juga memerlukan komitmen internal para pelaku di dalamnya, termasuk para peserta didik.

Namun pada kenyataannya, yang terjadi adalah sebagian besar pelajar menengah justru mengabaikan tugastugasnya, padahal tugas-tugas adalah sarana evaluasi. Dimana dari hasil evaluasi dapat dilihat seberapa efektif proses belajar yang sudah berlangsung. Selain itu, dapat mengukur perkembangan pengalaman belajarnya, sehingga dapat dievaluasi juga sistem pendidikan yang diterapkan.

Komitmen dalam tugas (task commitment) adalah motivasi internal yang mendorong orang untuk tekun dan ulet mengerjakan tugas, meskipun mengalami macam-macam rintangan, secara khusus adalah tugas akademik. Dewasa ini, mulai berkembang gejala yang menghawatirkan yakni adanya krisis motivasi termasuk di dalamnya krisis komitmen terhadap tugas (task commitment), terutama pada peserta didik tingkat sekolah menengah. Gejala lain diantaranya adalah berkurangnya perhatian peserta didik akan belajar, kelalaian dalam mengerjakan tugastugas, menunda persiapan tes, menunda pekerjaan rumah, serta berkembangnya pandangan "asal lulus" atau "asal naik kelas". Keluhan malas belajar dan cuek terhadap tugas sering kali masih terjadi pada anak sekolah.

Tugas yang diberikan oleh guru pada umumnya tidak dikerjakan, mungkin sekedar dikerjakan di sekolah pada hari itu, sehingga siswa bersikap masa bodoh pada pelajaran yang diberikan atau beberapa siswa juga ada yang mengerjakan tugas dengan asalasalan dan tidak bertanggung jawab akan tugasnya. Selalu mengerjakan tugas pagi-pagi di kelas sebelum mulai proses belajar mengajar, dengan seringnya alasan bahwa lupa akan tugas atau tidak bisa mengerjakan di rumah. Pada saat ada tugas kelompok, mereka asyik bercanda dengan teman satu kelompok dan ketika diingatkan oleh guru, peserta didik hanya menjawab seolah-olah meremehkan tugas yang diberikan. Peserta didik tersebut merasa tidak mempunyai tanggung jawab 
terhadap tugas yang sudah diberikan. Hal ini menunjukkan peserta didik tidak memiliki perilaku untuk lekat akan tugas. Peserta didik hanya menganggap pekerjaan rumah hanyalah sebuah kewajiban yang harus dikerjakan, jika tidak dikerjakan maka akan mendapatkan sanksi, yang akhirnya berkembang pendapat dari peserta didik "yang penting dikerjakan". Hal ini menunjukkan peserta didik tidak ada ketertarikan dan tidak ada perasaan lekat akan tugas.

Salah satu faktor yang memengaruhi komitmen terhadap tugas (task commitment) adalah persepsi peran (role perseptions), khususnya peran persepsi pada diri peserta didik. Menurut Hawadi (2001: 45), persepsi peran adalah pemahaman perilaku yang diperlukan atas suatu peran, tanggung jawab, dan tugas seorang individu. Dalam penelitian ini, secara terfokus adalah perihal persepsi pada peran peserta didik yang artinya pemahaman seorang remaja bersekolah tentang tugas dan tanggung jawabnya sebagai peserta didik. Seorang remaja bersekolah akan bersikap sesuai dengan peran, tugas dan tanggung jawabnya sebagai peserta didik, dipengaruhui oleh cara peserta didik tersebut memandang dan memahami tugas dan perannya sebagai peserta didik. Uraian di atas didukung oleh pendapat dari Locke dan Lathan (2002: 705), yang mengatakan bahwa "tingkah laku manusia termasuk di dalamnya komitmen internal dipengaruhi oleh pemahaman secara sadar tentang tugas dan perannya, rencana, niat, tugas, dan semacamnya".

Selain task commitment, prestasi belajar juga dipengaruhi oleh locus of control. Locus of control mengandung arti tingkat dimana individu yakin bahwa mereka penentu nasib mereka sendiri. Percaya pada kemampuan sendiri mempuyai tepat yakni sukses karena kemampuan yang dimiliki dan gagal karena kurang usaha menimbulkan motivasi individu di kemudian hari. Jadi, kemampuan dapat menjadi pengaruh terhadap motivasi di kemudian hari. Sedang sukses karena keberuntungan misal dengan tugastugas yang mudah dan gagalnya karena kurangnya kemampuan maka memungkinkan pemadaman minat.

Locus of control menjadi sangat penting bagi keberhasilan berupa prestasi belajar, karena locus of control mempangaruhi sukses dan gagalnya peserta didik. Banyak peserta didik yang sukses dalam prestasi belajarnya, karena mereka percaya akan kemampuan yang mereka miliki. Peserta didik yang tidak percaya akan kemampuannya dan lebih percaya dengan nasib atau hal lainnya, kemungkinan besar akan gagal.

Pada dasarnya, locus of control terbagi menjadi dua yaitu locus of control internal dan locus of control eksternal. Locus of control internal adalah individu-individu yang yakin bahwa mereka merupakan pemegang kendali atas apapun yang terjadi pada diri mereka, hasil adalah dampak langsung dari tindakannya. Sedangkan locus of control eksternal adalah individu-individu yang yakin bahwa apapun yang terjadi pada diri mereka dikendalikan oleh kekuatan luar seperti keberuntungan atau kesempatan.

Locus of control merupakan suatu indikator evaluasi diri karena individu berpikir bahwa mereka kurang memiliki kendali atas hidup mereka cenderung kurang memiliki rasa percaya diri. Sedangkan keberhasilan seseorang disebabkan oleh locus of control yang berbeda, baik untuk sukses maupun gagal. Saat menghadapi kegagalan, dianjurkan untuk menyikapi sebagai hal yang labil, yang terjadi bisa berlawanan. Ada yang menganggap keberhasilan 
karena ekonomi bagus dan lain-lain. Pada saat menghadapi kegagalan, menuduh faktor internal sebagai sebab. Sikap yang baik adalah menempatkan faktor internal dan eksternal sebagai kedua faktor yang saling mendukung.

Persepsi diri berhubungan dengan sukses atau gagal disebut juga locus of control. Terkait dengan locus of control, yang diteliti adalah tingkah laku peserta didik dalam belajar dan berpikir kreatif. Dorongan untuk mencapai locus of control adalah bagaimana seseorang mempersepsikan diri mereka sesuai dengan kontrolnya. Pada dasarnya, mutu pendidikan ditentukan oleh keberhasilan dalam proses belajar mengajar di kelas. Tingkat perubahan yang merupakan keberhasilan dalam proses belajar mengajar peserta didik ditandai dengan perolehan skor tes.

\section{METODE}

Penelitian ini dilaksanakan di SMK Pijar Alam Bogor yang merupakan bagian dari Yayasan Pijar Alam Indonesia. Alamat lengkap tempat penelitian berada di Jln. Raya Puri Panangga No. 99, Cileungsi, Kota Bogor, Jawa Barat. Penelitian dilaksanakan selama empat bulan di semester genap tahun pelajaran 2014/2015, yaitu bulan Maret s.d. Juni. Penelitian ini merupakan expost facto dan termasuk jenis penelitian korelasional dengan pendekatan kuantitatif. Pada penelitian ini, desain penelitian yang digunakan adalah analisis ANAVA dengan ordo $2 \times 2$. Desain penelitian pada penelitian ini digambarkan dengan paradigma penelitian (konstelasi) sebagai berikut:

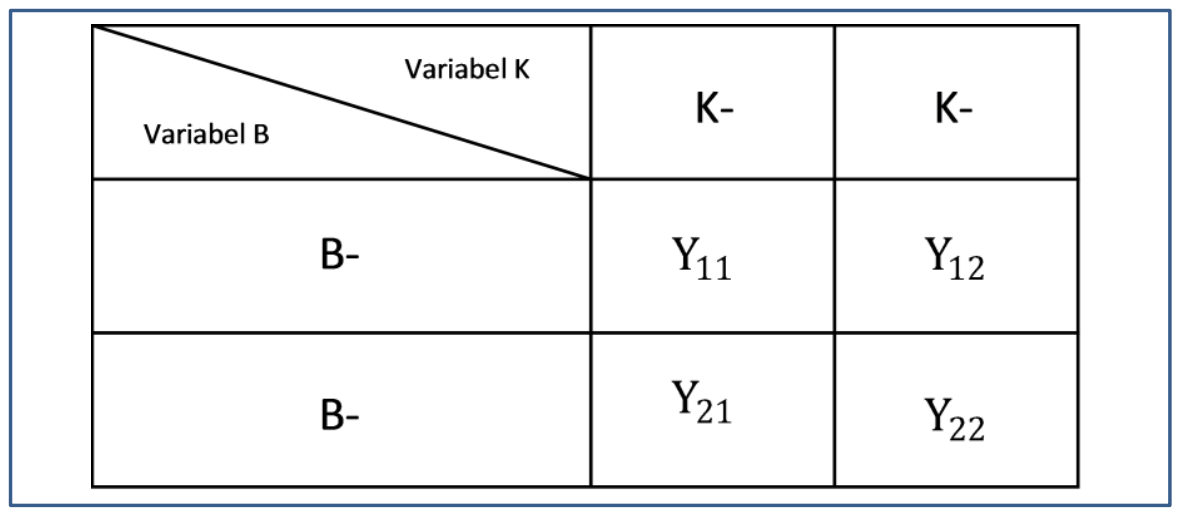

Keterangan:

\section{Gambar 1. Desain Penelitian}

$\mathrm{B}_{1}:$ Task commitment tinggi

$\mathrm{B}_{2}$ : Task commitment rendah

$\mathrm{K}_{1}$ : Locus of control internal

$\mathrm{K}_{2}$ : Locus of control eksternal

$\mathrm{Y}_{11}$ : Prestasi belajar matematika peserta didik dengan task commitment tinggi dan locus of control internal

$\mathrm{Y}_{12}$ : Prestasi belajar matematika peserta didik dengan task commitment tinggi dan locus of control eksternal

$\mathrm{Y}_{21}$ : Prestasi belajar matematika peserta didik dengan task commitment rendah dan locus of control internal

$\mathrm{Y}_{22}$ : Prestasi belajar matematika peserta didik dengan task commitment rendah dan locus of control eksternal 
Populasi target dari penelitian ini adalah seluruh peserta didik kelas $\mathrm{X}$ SMK Pijar Alam Bogor, yaitu 345 orang dari dua jurusan yang ada di tempat penelitian. Teknik kendaraan ringan 193 orang dan teknik komputer jaringan 152 orang, jadi total populasi target adalah 345 orang. Adapun populasi terjangkau dalam penelitian ini adalah peserta didik kelas X Teknik Komputer dan Jaringan tahun ajaran 2014/2015 sebanyak 152 peserta didik. Sampel pada penelitian ini adalah peserta didik SMK Pijar Alam Kota Bogor kelas X Teknik Komputer dan Jaringan sebanyak 60 orang dengan teknik pengambilan sampel dengan simple random sampling.

Sumber data dalam penelitian ini diperoleh dari peserta didik di SMK Pijar Alam Kota Bogor. Untuk variabel task commitment dan locus of control data diperoleh dari peserta didik dengan cara pengisian angket. Untuk variabel prestasi belajar matematika berupa catatan dokumen yang mana data diperoleh dari guru yaitu berupa nilai UTS matematika semester genap. Prestasi belajar matematika merupakan hasil usaha belajar peserta didik sebagai indikator tingkat ketercapaian tujuan belajar matematika dalam peguasaan struktur kognitif berupa fakta-fakta, konsep-konsep dan generalisasi setelah mendapatkan pengalaman belajar di bidang matematika. Prestasi belajar matematika dalam penelitian ini merupakan hasil usaha yang diperoleh peserta didik setelah mempelajari matematika selama beberapa waktu dan tingkatannya dapat dinyatakan dengan nilai, yang mana dalam hal ini didapat dari nilai Ujian Tengah Semester mata pelajaran matematika di semester genap.

Task commitment adalah suatu tekat yang kuat dalam diri sendiri yang tak menentukan dorongan dari luar untuk mencapai suatu prestasi yang ditunjukan dengan sikap-sikap berikut: tangguh, ulet, tidak mudah bosan, mandiri, menetapkan tujuan aspirasi yang realities dengan resiko sedang, suka belajar dan mempunyai hasrat untuk meningkatkan diri dan hasrat untuk berhasil di bidang akademis. Task commitment peserta didik pada pelajaran matematika adalah skor yang diperoleh dari hasil penilaian angket task commitment yang akan diukur dengan instrumen berbentuk angket yang berjumlah 30 pernyataan. Angket diisi oleh peserta didik dengan cara memilih penilaian pernyataan yang sudah disediakan untuk setiap butir pernyataan angket.

\begin{tabular}{|c|c|c|}
\hline \multirow{2}{*}{$\begin{array}{c}\text { Penilaian } \\
\text { Pernyataan }\end{array}$} & \multicolumn{2}{|c}{ Nilai Pernyataan } \\
\cline { 2 - 3 } & Positif & Negatif \\
\hline SS & 5 & 1 \\
\hline S & 4 & 2 \\
\hline RR & 3 & 3 \\
\hline TS & 2 & 4 \\
\hline STS & 1 & 5 \\
\hline
\end{tabular}

Keterangan:

$\begin{array}{ll}\text { SS } & \text { Sangat Setuju } \\ \text { S } & \text { Setuju } \\ \text { RR } & \text { : Ragu-ragu } \\ \text { TS } & \text { : Tidak Setuju } \\ \text { STS } & \text { : Sangat Tidak Setuju }\end{array}$

Ujicoba instrumen task commitment dilakukan dengan uji validitas dan uji reliabilitas yang dilaksanakan pada peserta didik sejumlah 30 orang. Hasil uji validitas diperoleh 26 butir pernyataan valid dan 4 butir pernyataan tidak valid. Adapun rentang skor korelasi Product Moment yaitu 0,235 s.d. 0,629. Kemudian hasil uji reliabilitas diperoleh nilai Alpha Cronbach sebesar 0,774, yang mana nilai ini memiliki kriteria tingkat reliabilitas yang tinggi. 
Locus of control adalah istilah yang digunakan untuk menunjukan keyakinan atau kepercayaan individu terhadap pengendalian-pengendalian pribadinya yang dipengaruhi oleh faktor yang akan berdampak pada hasil belajar yang diinginkan. Baik buruknya hasil belajar yang dicapai seorang individu, bergantung bagaimana individu tersebut berusaha untuk mencapainya dengan berbagai pengendalian. yang dilakukan akibat adanya peristiwa-peristiwa yang mempengaruhinya. Locus of control adalah suatu derajat kepercayaan bahwa kita merupakan penyebab atau mempunyai kontrol terhadap peristiwaperistiwa dalam kehidupan. Untuk mengetahui tingkat locus of control peserta didik terhadap pelajaran matematika digunakan instrumen berupa angket yang yang terdiri dari 30 pertanyaan. Angket diisi oleh peserta didik dengan cara memilih penilaian pernyataan yang sudah disediakan untuk setiap butir pernyataan angket.

\begin{tabular}{|c|c|c|}
\hline \multirow{2}{*}{$\begin{array}{c}\text { Penilaian } \\
\text { Pernyataan }\end{array}$} & \multicolumn{2}{|c|}{ Nilai Pernyataan } \\
\hline PL & 5 & 1 \\
\hline S & 4 & 2 \\
\hline KD & 3 & 3 \\
\hline P & 2 & 4 \\
\hline TP & 1 & 5 \\
\hline
\end{tabular}

Keterangan:

SL : Selalu

S : Sering

KD : Kadang-kadang

$\mathrm{P}$ : Pernah

TP : Tidak Pernah

Ujicoba instrumen locus of control dilakukan dengan uji validitas dan uji reliabilitas yang dilaksanakan pada peserta didik sejumlah 30 orang. Hasil uji validitas diperoleh 26 butir pernyataan valid dan 4 butir pernyataan tidak valid. Adapun rentang skor korelasi Product Moment yaitu 0,229 s.d. 0,585. Kemudian hasil uji reliabilitas diperoleh nilai Alpha Cronbach sebesar 0,760, yang mana nilai ini memiliki kriteria tingkat reliabilitas yang tinggi.

Teknik analisis terhadap data hasil penelitian yang dalam hal ini berupa nilai prestasi belajar matematika serta perolehan total skor atas angket task commitment dan locus of control dilakukan secara deskriptif dan inferensial. Secara deskriptif, data hasil penelitian dianalisis untuk skor mean, median, dan modus. Adapun maksud analisis skor mean, median, dan modus adalah untuk mendeskripsikan ukuran pemusatan data dari subjek penelitian. Secara inferensial, data hasil penelitian dianalisis dengan uji $\boldsymbol{F}$ untuk pengujian main effect dan interaction effect serta uji $\boldsymbol{t}$ untuk pengujian simple effect, dengan terlebih dahulu diuji untuk persyaratannya yaitu uji normalitas dan uji homogenitas. Perhitungan data hasil penelitian dilakukan dengan menggunakan bantuan software SPSS.

\section{HASIL DAN PEMBAHASAN}

\section{Hasil Penelitian}

Responden yang diambil peneliti adalah peserta didik kelas X SMK Pijar Alam Bogor pada tahun ajaran 2014/2015. Kelas X SMK Pijar Alam Bogor terdiri dari dua kelas yaitu kelas $\mathrm{X}$ Teknik Kendaraan Ringan dan kelas $X$ Teknik Komputer dan Jaringan. Selain heterogen dalam hal suku dan asal daerah, peserta didik yang mejadi sampel penelitian termasuk dalam kategori heterogen dalam hal tingkat kognitif, afektif, dan psikomotoriknya. 
Penelitian ini memiliki tiga variabel yaitu dua variabel bebas dan satu variabel terikat. Variabel bebas terdiri dari task commitment dan locus of control. Task commitment dibedakan menjadi dua kategori, yakni task commitment tinggi dan task commitment rendah. Locus of control juga terdiri dari dua jenis yaitu locus of control internal dan locus of control eksternal. Variabel terikat dalam penelitian ini adalah prestasi belajar matematika peserta didik kelas $\mathrm{X}$ yang diambil dari nilai UTS semester genap.

\section{Pengaruh Interaksi Task Commitment dan Locus Of Control Secara Bersama-sama Terhadap Prestasi Belajar Matematika Peserta Didik SMK Pijar Alam 2 Bogor.}

Berdasarkan pengujian hasil hipotesis menunjukan bahwa task commitmnet dan locus of control berpengaruh terhadap prestasi belajar matematika peserta didik. Hal ini dibuktikan dari hasil penelitian melalui Uji ANAVA Dua Arah $F_{\text {hitung }}>F_{\text {tabel }}$, yaitu $6,82>4,01$ sehingga ditarik simpulan terdapat bahwa pengaruh interaksi task commitment dan locus of control terhadap prestasi belajar matematika.

\section{Pengaruh Task Commitment terhadap Prestasi Belajar Matematika Peserta Didik SMK Pijar Alam 2 Bogor.}

Berdasarkan pengujian hasil hipotesis menunjukan bahwa task commitment berpengaruh terhadap prestasi belajar matematika peserta didik. Hal ini dibuktikan dari hasil penelitian melalui Uji ANAVA Dua Arah $\mathrm{F}_{\text {hitung }}>\mathrm{F}_{\text {tabel, }}$ yaitu 6,27 $>4,01$ sehingga ditarik simpulan terdapat bahwa pengaruh task commitment terhadap prestasi belajar matematika.
Dari hasil analisis deskriptif diketahui bahwa skor rata-rata prestasi belajar matematika peserta didik yang memiliki task commitment tinggi lebih baik jika dibandingkan dengan peserta didik yang memiliki Task commitmnet rendah. Hal ini menunjukkan bahwa prestasi belajar matematika dengan task commitment tinggi lebih baik dari pada peserta didik yang memiliki task commitment rendah.

3. Pengaruh Locus of Control Terhadap Prestasi Belajar Matematika Peserta Didik Kelas X SMK Pijar Alam Bogor.

Berdasarkan pengujian hasil hipotesis menunjukan bahwa locus of control berpengaruh terhadap prestasi belajar matematika peserta didik. Hal ini dibuktikan dari hasil penelitian melalui Uji ANAVA Dua Arah $F_{\text {hitung }}>F_{\text {tabel, }}$ yaitu 5,40 > 4,01 sehingga ditarik simpulan terdapat bahwa pengaruh locus of control terhadap prestasi belajar matematika.

Kelompok peserta didik yang memiliki locus of control internal secara keseluruhan menunjukkan perbedaan yang signifikan jika dibandingkan dengan peserta didik yang memilki locus of control eksternal. Jadi skor prestasi kelompok peserta didik yang memiliki locus of control internal secara signifikan lebih baik jika dibandingkan peserta didik yang memiliki locus of control eksternal. Hal ini menunjukkan peserta didik yang memiliki locus of control internal dan locus of control eksternal prestasi belajarnya berbeda, kondisi itu didapat sebagai bukti empirik bahwa pengelompokkan peserta didik yang didasarkan locus of control internal dan eksternal sangat efektif. 
4. Pengaruh sederhana (simple effect)

a. Pengaruh task commitment tinggi dan task commitment rendah terhadap locus of control internal.

Berdasarkan pada pengujian hipotesis dari hasil penelitian menunjukkan bahwa $t_{\text {hitung }}>t_{\text {tabel }}$ $(3,65>2,05)$ maka Ho ditolak. Disimpulkan terdapat pengaruh prestasi belajar matematika antara peserta didik yang memiliki task commitment tinggi dengan peserta didik yang memiliki task commitment rendah pada peserta didik yang memiliki locus of control internal.

b. Pengaruh task commitment tinggi dan task commitment rendah terhadap locus of control eksternal.

Berdasarkan pada pengujian hipotesis dari hasil penelitian menunjukkan bahwa $t_{\text {hitung }}<\mathrm{t}_{\text {tabel }}$ $(0,16<2,05)$ maka Ho diterima. Disimpulkan bahwa tidak terdapat pengaruh prestasi belajar matematika yang signifikan antara peserta didik yang memiliki task commitment tinggi dan peserta didik yang memiliki task commitment rendah pada peserta didik yang memiliki locus of control eksternal.

c. Pengaruh locus of control internal dan locus of control eksternal terhadap task commitment tinggi.

Berdasarkan pada pengujian hipotesis dari hasil penelitian menunjukkan bahwa $t_{\text {hitung }}>t_{\text {tabel }}$ $(3,30>2,05)$ maka $\mathrm{H}_{0}$ ditolak. Disimpulkan bahwa terdapat pengaruh prestasi belajar matematika peserta didik yang memiliki locus of control internal dengan peserta didik yang memiliki locus of control eksternal pada peserta didik yang memiliki task commitment tinggi. d. Pengaruh locus of control internal dan locus of control eksternal terhadap task commitment rendah.

Berdasarkan pada pengujian hipotesis dari hasil penelitian menunjukkan bahwa $t_{\text {hitung }}<t_{\text {tabel }}$ $(0,07<2,05)$ maka $\mathrm{H}_{0}$ diterima. Disimpulkan bahwa tidak terdapat pengaruh prestasi belajar matematika yang signifikan antara peserta didik yang memiliki locus of control internal dengan peserta didik yang memiliki locus of control eksternal pada peserta didik yang memiliki task commitment rendah.

\section{Pembahasan Hasil Penelitian}

Pendidikan merupakan salah satu hal yang penting dalam kehidupan berbangsa dan bernegara. Sumber daya manusia yang mampu bersaing dan berkualitas adalah salah satu faktor penentu dalam peningkatan segala aspek kehidupan. Melihat begitu pentingnya pendidikan, menjadikan pendidikan sebagai hal yang wajib dilaksanakan secara berkesinambungan guna menjawab berbagai tantangan zaman. Bidang pendidikan harus menjadi salah satu prioritas pembangunan kehidupan berbangsa dan bernegara bisa lebih maju.

Penunjang keberhasilan prestasi belajar, kebiasaan belajar yang baik dan disiplin harus dimiliki peserta didik, selain itu kebutuhan untuk berprestasi tinggi dan daya saing tinggi harus selalu diutamakan dalam diri peserta didik. Jika hal ini dilakukan maka keberhasilan peserta didik akan lebih mudah untuk dicapai. Diantara sekian banyak faktor, ada faktor-faktor yang langsung memengaruhi prestasi belajar, diantaranya berupa kecemasan, disiplin, efikasi diri, task commitment, locus of control, dan lain-lain. 
Task commitment yaitu suatu tekad yang kuat dalam diri sendiri yang menentukan dorongan dari luar untuk mencapai suatu prestasi yang ditunjukkan dengan sikap tangguh, ulet, tidak mudah bosan; mandiri; menetapkan tujuan aspirasi yang realistis dengan resiko sedang; suka belajar dan mempunyai hasrat untuk meningkatkan diri dan mempunyai hasrat untuk berhasil di bidang akademis. Aspek-aspek dalam task commitment diantaranya yaitu menentukan arah (menentukan tujuan), menentukan pilihan dan regulasi. Peserta didik yang memiliki task commitment yang tinggi akan sangat berpengaruh pada saat menyelesaikan soal-soal matematika yang ditemuinya, karena sikap tangguh, ulet dan tidak mudah bosan itu yang akan membuat peserta didik itu sendiri semakin memotivasi dirinya sampai dapat menyelesaikan soal-soal yang dihadapinya. Individu yang mempunyai task commitment tinggi selalu mencari cara satu, dua, tiga dan seterusnya sampai dapat menyelesaikan persoalan yang dihadapinya.

\begin{tabular}{rrr}
\multicolumn{1}{c}{ Locus of control merupakan } \\
istilah yang & digunakan untuk \\
menunjukkan & keyakinan & atau
\end{tabular} kepercayaan individu terhadap pengendalian-pengendalian pribadinya yang dipengaruhi oleh banyak faktor, yang akan berdampak pada hasil belajar yang diinginkan. Baik buruknya hasil belajar yang dicapai seseorang, bergantung bagaimana cara individu tersebut berusaha untuk mencapainya dengan berbagai pengendalian yang dilakukan akibat adanya peristiwaperistiwa yang mempengaruhinya. Individu yang memiliki locus of control yang tinggi merupakan seorang yang dapat mengendalikan dirinya lebih baik dan percaya usaha yang dilakukannya akan membuat dirinya berhasil, sehingga individu tersebut cenderung akan aktif mencari informasi dan pengetahuan yang baru. Dengan demikian, locus of control dapat mempengaruhi prestasi belajar peserta didik, karena peserta didik yang memiliki keyakinan bahwa dirinya mampu menyelesaikan soal matematika akan lebih berkosentrasi dan mampu menyelesaikannya dengan baik.

Menciptakan pendidikan yang berkualitas bukan hanya mengandalkan pemerintah melainkan membutuhkan dukungan dari beberapa pihak seperti guru dan peserta didik. Beberapa faktor pendukung prestasi belajar matematika antara lain: mempunyai task commitment yang tinggi, memiliki locus of control internal, disiplin, konsisten, minat belajar, dan lain sebagainya. Tidak semua peserta didik menyukai matematika. Hal tersebut disebabkan karena matematika dianggap sebagai mata pelajaran yang sukar dan sulit dalam menyelesaikanya. Atau dengan kata lain, peserta didik sudah bersikap bahwa mata pelajaran matematika itu membosankan, menakutkan, bersifat abstrak, penuh dengan angka-angka dan rumus. Selain itu juga karena masih ada sistem belajar yang menyamakan kemampuan peserta didik, kurangnya motivasi dari guru, metode pembelajaran yang kurang menarik dan membosankan.

Seperti yang dijelaskan sebelumnya, beberapa faktor yang mempengaruhi prestasi belajar peserta didik salah satunya task commitment. Task commitment sangat berpengaruh terhadap prestasi belajar matematika peserta didik, selain task commitment ada faktor lain yang mempengaruhi prestasi belajar matematika yaitu locus of control. Selain adanya pengaruh masing-masing dari task commitment dan locus of control terhadap prestasi belajar matematika. 


\section{SIMPULAN DAN SARAN}

\section{Simpulan}

Hasil penelitian tentang pengaruh task commitment dan locus of control terhadap prestasi belajar matematika yang dilakukan di SMK Pijar Alam Bogor, pada peserta didik kelas $\mathrm{X}$ dengan jumlah sampel 60 peserta didik. Setelah dilakukan pengambilan data dan dilanjutkan dengan analisa data hasil penelitian serta melalui pengujian hipotesis berupa Uji ANAVA dua jalur, akhirnya peneliti dapat ambil tiga buah simpulan, yaitu: pertama: terdapat pengaruh interaksi antara task commitment dan locus of control secara bersama-sama terhadap prestasi belajar matematika pada peserta didik kelas $\mathrm{X}$ di SMK Pijar Alam Bogor; kedua: terdapat pengaruh task commitment terhadap prestasi belajar matematika pada peserta didik kelas X di SMK Pijar Alam Bogor; dan ketiga: terdapat pengaruh locus of control terhadap prestasi belajar matematika pada peserta didik kelas X di SMK Pijar Alam Bogor.

\section{Saran}

Penelitian ini dimaksudkan untuk mengetahui secara lebih mendetail pengaruh task commitment dan locus of control terhadap prestasi belajar matematika pada peserta didik kelas X di SMK Pijar Alam Bogor. Dengan berpedoman pada hasil penelitian yang ada, beberapa saran dapat dituangkan untuk lebih memperbaiki prestasi belajar matematika peserta didik, diantaranya: segenap akademisi dan praktisi pendidikan dapat mengkaji lebih luas dan mendalam lagi terkait dengan konsep task commitment, locus of control, dan prestasi belajar untuk mata pelajaran matematika.
Hal ini dimaksudkan untuk dapat menambah bahan kajian untuk penelitian selanjutnya, dan juga dapat menambah literatur bacaan, sehingga baik secara langsung maupun tidak langsung dapat menambah wawasan keilmuan. Kemudian, pihak sekolah dapat memfasilitasi guru dalam menggunakan metode-metode pengajaran baru agar meningkatkan kreativitas guru dalam pengajaran dan membuka kemungkinan besar tercapainya keberhasilan pembelajaran yang tercerminkan oleh tingginya prestasi belajar peserta didik.

Guru matematika hendaknya memerhatikan bahwa keberhasilan dalam mata pelajaran matematika tidak serta merta sepenuhnya dipengaruhi oleh tingkat intelegensi saja, melainkan ada faktor lain seperti task commitment dan locus of control peserta didik. Orangtua hendaknya menumbuhkan kepercayaan diri peserta didik terutama dalam hal kemandirian belajar baik di rumah maupun di sekolah dengan memberikan kebebasan namun bertanggung jawab. Para orangtua dari peserta didik juga hendaknya tidak otoriter dalam mengatur waktu belajar, jauh lebih penting adalah menjadi teladan atas pembinaan task commitment dan locus of control.

Peserta didik diharapkan untuk dapat lebih memupuk dan menumbuhkembangkan segenap konsep terkait task commitment dan locus of control, sehingga diperoleh hasil belajar matematika yang lebih baik. Bagi para peneliti lain, hasil penelitian ini hendaknya dapat dijadikan sebagai salah satu referensi atau sumber rujukan yang dapat dijadikan sebagai bahan kajian untuk peneliti selanjutnya, menjadikan hasil penelitian menjadi bahan bacaan atau literatur bagi semua. 


\section{DAFTAR RUJUKAN}

Agustian, A. G. 2001. Rahasia Sukses Membangun Kecerdasan Emosi dan Spiritual ESQ Berdasarkan 6 Rukun Iman dan Rukun Islam. Jakarta: Penerbit Arga.

Bety dan Laily. 2013. Pengaruh locus of control terhadap hasil belajar mahasiswa akuntansi. Jurnal pendidikan, 11(2): 17.

Djiwandono, S. E. W. 2002. Psikologi Pendidikan. Jakarta: Grafindo.

Hawadi, R. A. 2002. Identifikasi Keberbakatan Intelektual Melalui metode Non Tes. Jakarta: Grasindo.

Locke, E. A. dan Latham, G. P. 2002. Building a Practically Useful Teori of Goal Setting and Task Motivasion. American Psichologyst vol. 57 no 9.

Razali, R, Jantan, S., dan Hasyim. 2004. Psikologi Pendidikan. Pahang: PTS Internasional.

Robbins dan Jugde. 2008. Perilaku Organisasi. Jakarta: Salemba Empat.

Soedjadi. 2000. Kiat Pendidikan Matematika di Indonesia. Jakarta: Depdikbud.

Syafira, M. dan Sulistiani. 2011. Hubungan antara Dukungan Orang Tua dengan Komitmen terhadap Tugas (Tak Commitment) pada Siswa Akselarasi tingkat SMA. Jurnal pendidikan 13 (1): 3.

Widyaninggar, A. A. 2014. Pengaruh Efikasi Diri dan Lokus kendali (Locus of Control) terhadap Presatasi belajar Matematika. Jurnal formatif, 4(2): 92.

Wijayanti dan Taman, A. 2012. Pengaruh Perhatian Orang Tua dan Locus of Control Terhadap Prestasi Belajar Akuntasi Siswa SMK Batik Perbaikan Purworejo. Jurnal pendidikan, 5(2): 151-152. 